\title{
DINOL Gene
}

National Cancer Institute

\section{Source}

National Cancer Institute. DINOL Gene. NCI Thesaurus. Code C132161.

This gene plays a role in p53-dependent responses to DNA damage. 